\title{
The Effect of Gastrin on Basal- and Glucose-Stimulated Insulin Secretion in Man
}

\author{
Jens F. Rehfeld and Flemming Stadil \\ From the Department of Clinical Chemistry, Bispebjerg Hospital, and \\ Department of Gastroenterology C, Rigshospitalet, \\ Copenhagen, Denmark
}

A в S T R A C T The effect of gastrin on basal- and glucose-stimulated insulin secretion was studied in 32 normal, young subjects. The concentration of gastrin and insulin in serum was measured radioimmunochemically.

Maximal physiologic limit for the concentration of gastrin in serum was of the order of 160 pmol per liter as observed during a protein-rich meal. Oral ingestion of $50 \mathrm{~g}$ glucose produced a small gastrin response from $28 \pm 3$ to $39 \pm 5$ pmol per liter (mean $\pm \operatorname{SEM}, P<0.01$ ).

Intravenous injection or prolonged infusion of gastrin increased the concentration of insulin in peripheral venous blood to a maximum within $2 \mathrm{~min}$ followed by a decline to basal levels after a further $10 \mathrm{~min}$. The minimum dose required to induce a significant insulin response (31.2 $\mathrm{ng}$ gastrin per $\mathrm{kg}$ ) increased the gastrin level in serum above the physiologic range. Maximum effect was obtained with $500 \mathrm{ng}$ gastrin per $\mathrm{kg}$.

When $15.6 \mathrm{ng}$ (7.1 pmol) gastrin per kg body weight and $25 \mathrm{~g}$ glucose were injected simultaneously, the glucose-induced insulin response was potentiated (from 2.32 \pm 0.33 to $4.33 \pm 0.98 \mathrm{nmol}$ per liter per $20 \mathrm{~min}, P<0.02$ ), even though gastrin concentrations only increased to $71.2 \pm 6.6$ pmol per liter. No effect, however, was noted on glucose disposal. $15.6 \mathrm{ng}$ gastrin per $\mathrm{kg}$ given i.v. 30 min before an i.v. glucose tolerance test was without significant effect on the insulin response.

The results indicate that gastrin can stimulate a rapid and short-lived release of insulin. In physiologic concentrations gastrin potentiates the glucose-stimulated insulin secretion and is without effect on basal insulin secretion. A small release of gastrin during oral glucose ingestion may to a limited extent contribute to the nonglycemic insulin secretion. During protein ingestion, gastrin probably stimulates insulin secretion significantly.

This work was presented in part at the International Symposium on "The impact of insulin on metabolic pathways," 26 October 1971, Jerusalem, Israel.

Received for publication 27 November 1972 and in revised form 29 January 1973.

\section{INTRODUCTION}

Gastrointestinal hormones probably contribute significantly to the stimulation of insulin secretion during ingestion of glucose or protein (1-4). It has been suggested that more than half the insulin response to oral intake of glucose is caused by enteric hormones (5). At the present time there is a considerable debate as to which hormone or hormones mediate the insulin response.

Concerning the action of gastrin on insulin secretion, stimulation (6-11), no effect (12-16), as well as inhibition (17) have been reported. The conflicting results may in part be due to the use of pharmacological doses of crude preparations or fragments of gastrin. However, radioimmunoassay techniques for gastrin are now at hand (18-21), and hence the physiologic action of gastrin can be assessed.

In the present study the effect of endogenous and exogenous human gastrin on basal- and glucose-stimulated insulin secretion in man has been investigated and monitored by means of reliable radioimmunoassays for human gastrin and insulin.

\section{METHODS}

\section{Experimental procedures}

32 normal nonobese subjects, 24 males and 8 females, all members of the paramedical staff and aged from 24 to 42 yr participated in the study. They all had normal oral and i.v. glucose tolerance tests, and none had close relatives with diabetes mellitus. Informed consent was obtained from each subject.

The subjects were on a diet containing at least $250 \mathrm{~g}$ carbohydrates per day 3 days before each investigation. After an overnight fast the examination began between 8:00 and 9:00 a.m. Blood samples were collected from an i.v. canula inserted into an antecubital vein. After separation serum was stored at $-20^{\circ} \mathrm{C}$ until assayed.

Studies on the release of endogenous gastrin and its relation to insulin secretion

Protein-rich meal. Eight subjects, five females and three males, were given an appetizing meal composed of beef- 
steak, sauce, vegetables, and a glass of water (22). The subjects were told to eat as much as they liked, and the meal was finished after 20 min. Blood samples were drawn 15 , 10 , and $5 \mathrm{~min}$ before, and $2,5,10,20,30,45,60,90$, and 120 min after the onset of the meal.

Oral glucose loading. 20 subjects, 5 females and 15 males, were given $50 \mathrm{~g}$ of oral glucose in a $25 \%$ solution, flavored with lemon. Blood samples were drawn 15,10 , and $5 \mathrm{~min}$ before the loading, and $5,10,15,20,30,40,50,6090,120$, 150 , and $180 \mathrm{~min}$ after.

Intravenous glucose infusions. $1 \mathrm{wk}$ after the oral load the 20 subjects were submitted to an i.v. glucose infusion designed to copy the changes in blood glucose concentrations found during the oral load. $16^{2} \mathrm{~g}$ glucose in concentrations from 33 to $50 \%$ were given at a constant flow rate by an infusion pump in an antecubital vein. Blood samples were drawn from the opposite arm at intervals identical with those in the oral glucose test.

\section{Studies on the effect of exogenous gastrin on insulin secretion}

Intravenous infusion of gastrin. In five subjects, one female and four males, synthetic human gastrin I (SHG I from Imperial Chemical Industries, Cheshire, England) was given i.v. as a rapid injection of $62.5 \mathrm{ng}$ per $\mathrm{kg}$ body weight followed by $30 \mathrm{~min}$ infusion of $12.5 \mathrm{ng}$ SHG/kg per min. Blood samples were drawn $60,45,30$, and 15 min

${ }^{1}$ Abbreviation used in this paper: SHG, synthetic human gastrin I. before, and $0,2,5,10,20,30,45,60,75$, and $90 \mathrm{~min}$ after the onset of infusion. Gastric acid was aspirated continuously by intermittent pump suction through a nasogastric tube and collected in 15-min samples. The position of the tube was checked by fluoroscopy.

Dose-response studies with gastrin given intravenously. Each of six subjects was given seven doses of gastrin (15.6, $31.2,62.5,125,250,500,1,000 \mathrm{ng}$ per $\mathrm{kg}$ body weight). Pyrogen-tested SHG was dissolved in $0.1 \mathrm{M}$ sodium phos-

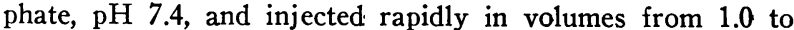
$5.0 \mathrm{ml}$. Venous blood samples were drawn 15,10 , and $5 \mathrm{~min}$ before, and $1,2,3,4,5,7,10,15$, and $20 \mathrm{~min}$ after the injection. In a few cases samples were also drawn $30 \mathrm{~min}$ after injection. The doses were given in randomized order.

Dose-response studies with gastrin and $25 \mathrm{~g}$ glucose given simultaneously intravenously. In six subjects three doses of SHG (15.6, 62.5, and $250 \mathrm{ng}$ ) were injected together with $25 \mathrm{~g}$ glucose in a $50 \%$ solution. The subjects were tested previously with an i.v. $25 \mathrm{~g}$ glucose tolerance test without gastrin. Blood samples were drawn 15, 10, and 5 min before, and $1,2,3,4,5,7,10,15,20,30,40,50$, and $60 \mathrm{~min}$ after the injection.

Studies on the effect of gastrin injected before glucose. In four subjects, three men and one woman, $25 \mathrm{~g}$ glucose was given twice with an interval of $150 \mathrm{~min}$ as described by Kraegen, Chisholm, Young, and Lazarus (35). 1 wk later the experiment was repeated with $15.625 \mathrm{ng}$ gastrin per $\mathrm{kg}$ injected $30 \mathrm{~min}$ before the second glucose injection. Blood samples were drawn according to the following scheme: $-5,0,2,5,10,20,30,45,60,75,90,105,120$,
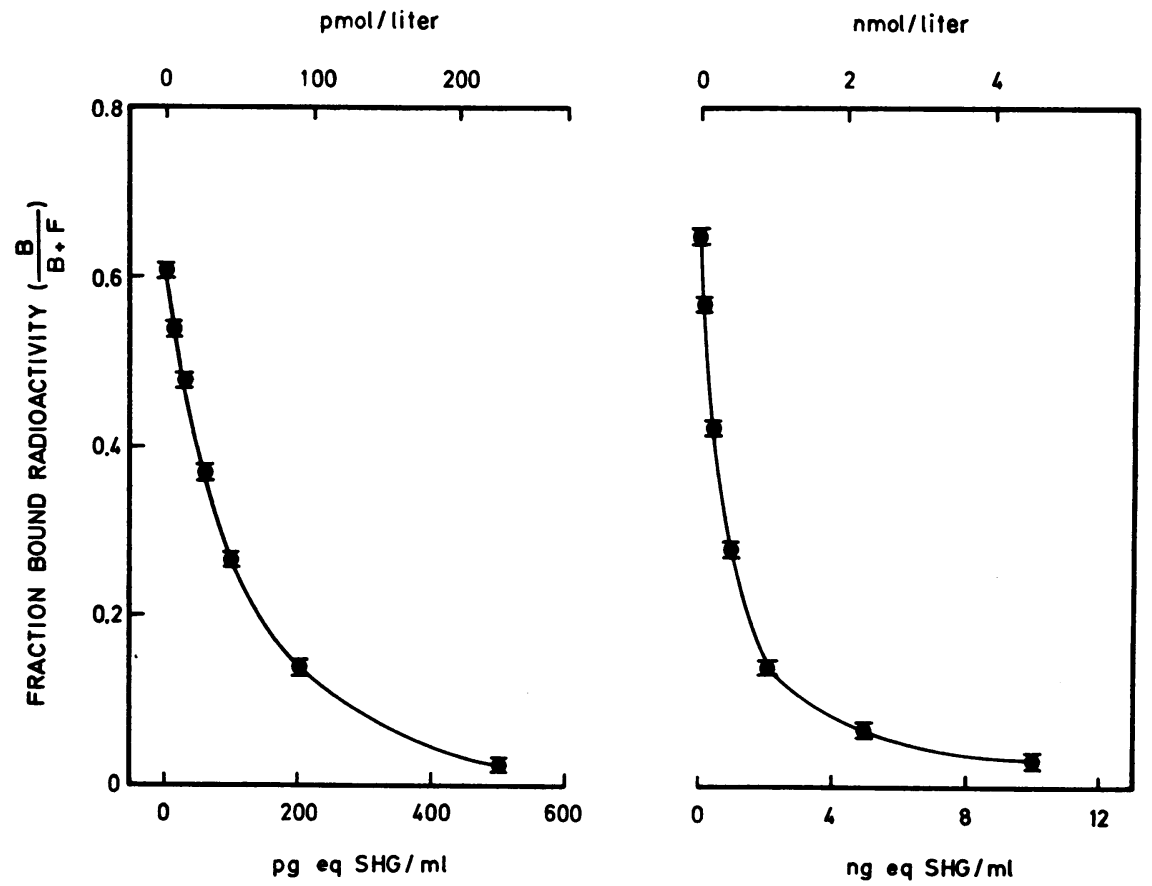

FIGURE 1 Standard calibration curves for the radioimmunoassay of gastrin. To the left a standard curve employed for determination of serum gastrin concentrations in the physiological range (0-300 pg eq $\mathrm{SHG} / \mathrm{ml} \sim 0-140 \mathrm{pmol} / \mathrm{liter}$, antiserum 2604). To the right a standard for determinations of serum gastrin concentrations above the physiologic range (antiserum 2609). The points on the standard curves are indicated as mean \pm SD from 10 replicate determinations. 
$122,125,130,140,150,152,155,160,170,180,195,210 \mathrm{~min}$. Gastric juice was collected as before.

\section{Laboratory methods}

Serum gastrin concentrations were measured with a radioimmunoassay (21) using a purified monoiodinated gastrin preparation (23). The antisera used (2604 and 2609) were produced in rabbits against synthetic hexadecapeptide gastrin (2-17) covalently coupled by carbodiimide to bovine serum albumin (24). The binding energy, expressed by the average equilibrium constant, was $1.1 \times 10^{12}(2604)$ and $4.4 \times 10^{10}$ liters $/ \mathrm{mol}(2609)$. The detection limit of the assays was $<20 \mathrm{fmol}$ gastrin per liter (2604) and $<2$ pmol per liter incubation mixture (2609). The working range of the assay was 2-140 (2604) and 100-5,000 pmol per liter (2609). Antiserum 2604 was used to measure physiologic concentrations of gastrin in serum, whereas antiserum 2609 was reserved for sera with high concentrations of gastrin (Fig. 1). The specificity of the assay was expressed by the molar ratio between the inhibition dose 50 for SHG and highly purified cholecystokinin. For antiserum 2604 the ratio was 0.006 , and for antiserum 2609 it was 0.002 . No other known hormone cross-reacted with the antisera. Within-assay precision was tested by 10 determinations of two serum samples. Mean-gastrin concentration $\pm 1 \mathrm{SD}$ was $84.4 \pm 3.9$ pmol per liter and $13.4 \pm 4.8$ pmol per liter respectively. Between-assay reproducibility was tested during 21 assays covering a period of $4 \mathrm{mo}$; for three sera the mean and standard deviations were $24.0 \pm 0.8,8.1 \pm 1.8$, and $43.4 \pm 3.0$ pmol per liter. The relative accuracy was estimated by comparison of reference concentrations with those reported by other groups. In our laboratories the mean concentration of gastrin in serum from healthy, fasting subjects was found to be $23.6 \pm 2.1 \mathrm{pmol}$ per liter or $52.0 \pm 4.6 \mathrm{pg}$ eq SHG per $\mathrm{ml}( \pm \mathrm{SEM}, \mathrm{n}=120)$. These concentrations are of the same order as those reported by others (18-20, 25). Superimposable dose-response curves were obtained with synthetic human gastrin in serum freed of gastrin, and with serial dilutions of sera. Measurements of gastrin concentrations in sera with added exogenous gastrin, in dilutions of sera, and in mixtures of sera with different concentrations yielded results, which deviated less than $10 \%$ from the expected values.

Serum insulin concentrations were measured by means of a wick-chromatographic radioimmunoassay (26). The working range of the assay was $35-1,400$ pmol per liter with a detection limit $<10$ pmol per liter. The employed antiserum measured both proinsulin and insulin. Within-assay precision was tested by 10 determinations of three serum samples. Mean $\pm 1 \mathrm{SD}$ was $70.7 \pm 3.4(10.2 \pm 0.6 \mu \mathrm{U}$ per $\mathrm{ml})$, $149.8 \pm 2.8(21.7 \pm 0.4 \mu \mathrm{U}$ per $\mathrm{ml})$, and $350.5 \pm 9.7$ pmol per liter $(50.8 \pm 1.4 \mu \mathrm{U}$ per $\mathrm{ml})$. Between-assay reproducibility was tested during 50 assays covering a period of $6 \mathrm{mo}$. For three sera the mean and 1 SD were $70.6 \pm 8.5(10.2 \pm 1.5$ $\mu \mathrm{U}$ per ml), $150.0 \pm 8.4(21.8 \pm 1.2 \mu \mathrm{U}$ per $\mathrm{ml})$, and 350.5 \pm 24.1 pmol per liter $(50.8 \pm 3.5 \mu \mathrm{U}$ per $\mathrm{ml})$. The mean concentration of insulin in serum in healthy fasting subjects was $58.0 \pm 4.2$ pmol per liter $( \pm S E M, n=120)$ or $8.4 \pm 0.6 \mu \mathrm{U}$ per $\mathrm{ml}$ in our laboratory. Measurement of insulin concentration in sera with added exogenous insulin, in dilutions of sera, and in mixtures of sera with different concentrations yielded results, which deviated less than $10 \%$ from the expected values.

Blood glucose concentrations were measured with a glucose oxidase method on Technicon Auto Analyzer (Technicon Instruments Corp., Tarrytown, N. Y.).
Gastric acid was measured by titration with $0.2 \mathrm{~N}$ sodium hydroxide to $\mathrm{pH}$ 7.0, employing an Autotitrator (Radiometer, Copenhagen, Denmark).

Calculations. The integrated insulin response and integrated gastrin stimulus were computed as the area under the serum insulin and serum gastrin curves in the time intervals indicated using fasting levels as base line. The glucose disappearance rate was calculated as $\mathrm{K}=\ln 2 / \mathrm{t} \frac{1}{2} \times$ 100 from the studies with i.v. glucose administration. The significance of differences between means was tested by Student's $t$ test. The concentrations of blood glucose, serum insulin, and serum gastrin are given as mean \pm SEM in molar units. Concentration units used by others, e.g., $\mathrm{mg} /$ $100 \mathrm{ml}, \mu \mathrm{U} / \mathrm{ml}$, and $\mathrm{pg} / \mathrm{ml}$, are indicated in brackets in the text.

In the tables conventional units are used.

\section{RESULTS}

\section{Studies on endogenous gastrin}

Response to a protein-rich meal (Fig. 2). Blood glucose concentrations showed an initial small decrease from $3.85 \pm 0.15(69.3 \pm 2.7 \mathrm{mg}$ per $100 \mathrm{ml})$ to $3.76 \pm 0.15$ mmol per liter $(67.7 \pm 2.7 \mathrm{mg}$ per $100 \mathrm{ml})$. The peak concentration of $4.74 \pm 0.42 \mathrm{mmol}$ per liter $(85.3 \pm 7.6 \mathrm{mg}$ per $100 \mathrm{ml}$ ), was observed after $45 \mathrm{~min}$.

The increase in serum insulin concentration appeared later than the increase in gastrin concentrations. The
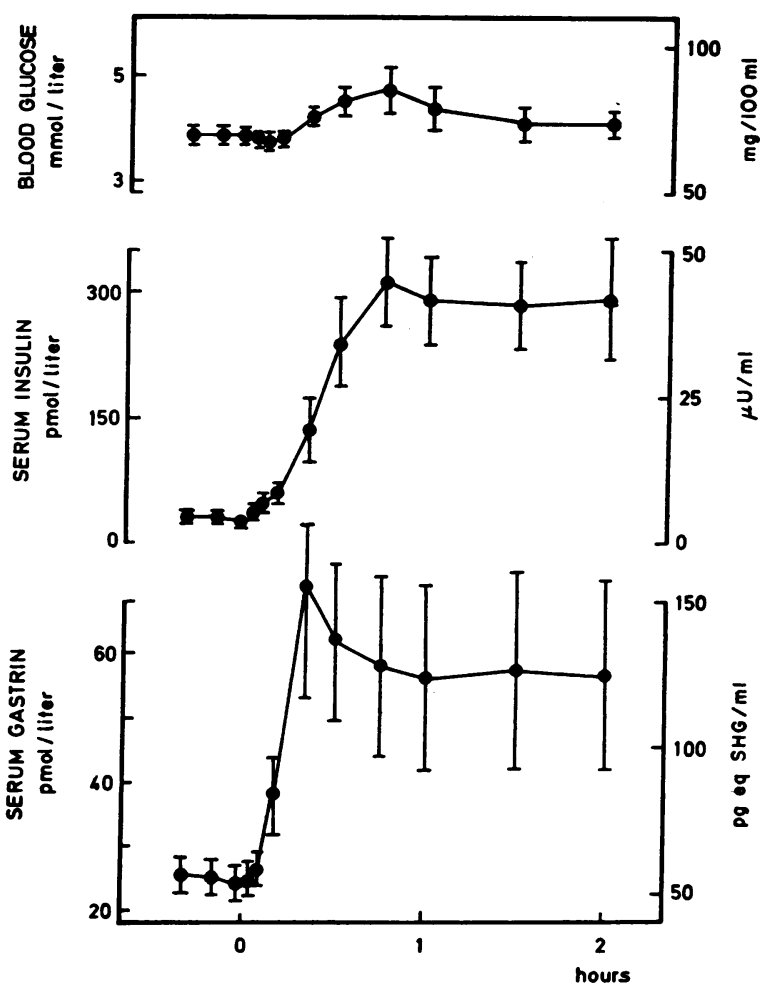

FIGURE 2 Blood glucose, serum insulin, and serum gastrin concentrations during a protein-rich meal. The concentrations are indicated as mean $\pm \operatorname{SEM}(n=8)$. 

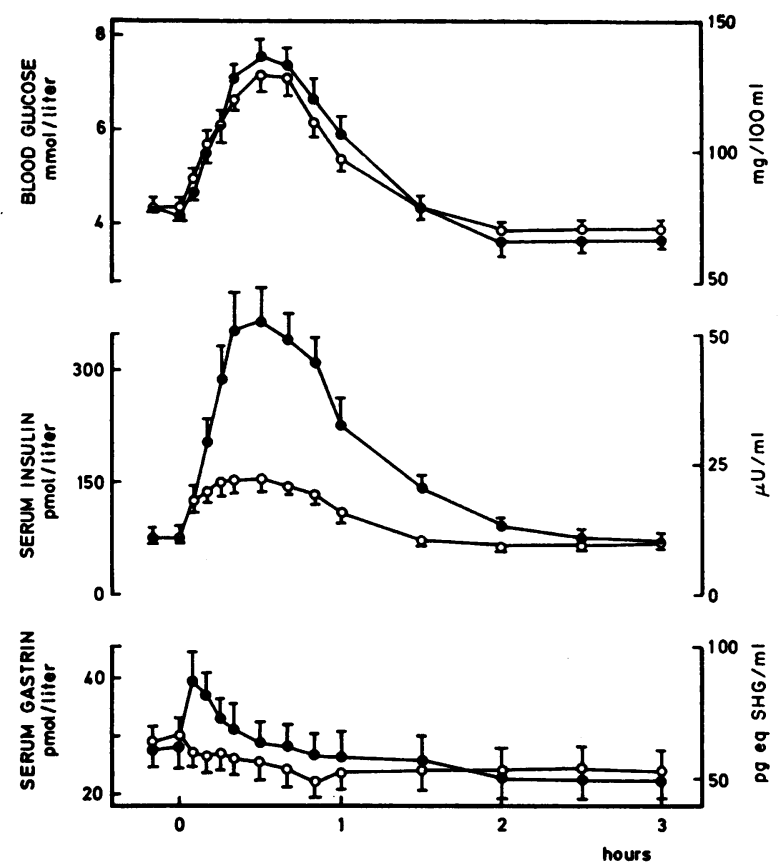

FIgURE 3 Blood glucose, serum insulin, and serum gastrin concentrations during a $50 \mathrm{~g}$ oral glucose load $(\bullet)$ and a $16.7 \mathrm{~g}$ i.v. glucose infusion $(\mathrm{O})$. The concentrations are indicated as mean $\pm \operatorname{SEM}(n=20)$.

highest concentration was found after $45 \mathrm{~min}(314 \pm 51$ pmol per liter) $(44.9 \pm 7.3 \mu \mathrm{U}$ per $\mathrm{ml})$. The integrated insulin response was $28.2 \pm 5.9 \mathrm{nmol}$ per liter $(4.3 \pm 0.8$ $\mathrm{mU}$ per $\mathrm{ml}$ ) per the two $1 \mathrm{st} \mathrm{h}$ of the meal.

Serum gastrin concentrations increased rapidly after the start of the meal. The maximum concentration (70.6 \pm 17.5 pmol per liter) (155.3 $\pm 38.5 \mathrm{pg}$ eq SHG per $\mathrm{ml})$ was reached in $20 \mathrm{~min}$. The integrated gastrin response during $2 \mathrm{~h}$ after onset of the meal was $4.1 \pm 1.6 \mathrm{nmol}$ per liter $(9.0 \pm 3.5 \mathrm{ng}$ eq SHG per $\mathrm{ml})$.

Response to oral glucose loading (Fig. 3). Variations in blood glucose and serum insulin concentrations are given in the figure. The basal gastrin concentration of $28.0 \pm 3.5$ pmol per liter (61.6 $\pm 7.7 \mathrm{pg}$ eq SHG per $\mathrm{ml}$ ) rose in $5 \mathrm{~min}$ to $39.0 \pm 5.6 \mathrm{pmol}$ per liter $(85.8 \pm 12.3 \mathrm{pg}$ eq SHG per $\mathrm{ml}$ ), and was followed by a slow decrease. The maximum concentrations differed from the fasting levels $(P<0.01)$.

Response to intravenous glucose infusion (Fig. 3). The glucose infusion produced variations in mean glucose concentrations in the blood almost similar to the ones observed during the oral glucose tolerance test.

The increase in insulin concentrations was less than during the oral glucose loading and the difference was highly significant.

No significant changes in serum gastrin concentrations were found. There was, however, a tendency to- wards a decrease from the mean fasting levels of $30.2 \pm$ $2.7 \mathrm{pmol}$ per liter $(66.4 \pm 5.9 \mathrm{pg}$ eq SHG per $\mathrm{ml}$ ) to 24.8 \pm 3.5 pmol per liter $(54.6 \pm 7.7 \mathrm{pg}$ eq $\mathrm{SHG}$ per $\mathrm{ml})$ after $50 \mathrm{~min}$.

\section{Studies on exogenous gastrin}

Response to intravenous infusion of gastrin (Fig. 4). Blood glucose concentrations rose modestly. The mean concentration for the 20th, 30th, 45th, and 60th min was significantly above the mean of the four basal concentrations $(P<0.02)$.

Insulin concentrations rose promptly within $2 \mathrm{~min}$ to $118.0 \pm 20.7$ pmol per liter $(16.2 \pm 3 \mu \mathrm{U}$ per $\mathrm{ml})$, but decreased to basal levels after $20 \mathrm{~min}$. Serum gastrin levels rose immediately. Peak concentration was observed after $30 \mathrm{~min}$.

The peak acid output was found in the 15 min collection made $45 \mathrm{~min}$ after the start of the infusion.

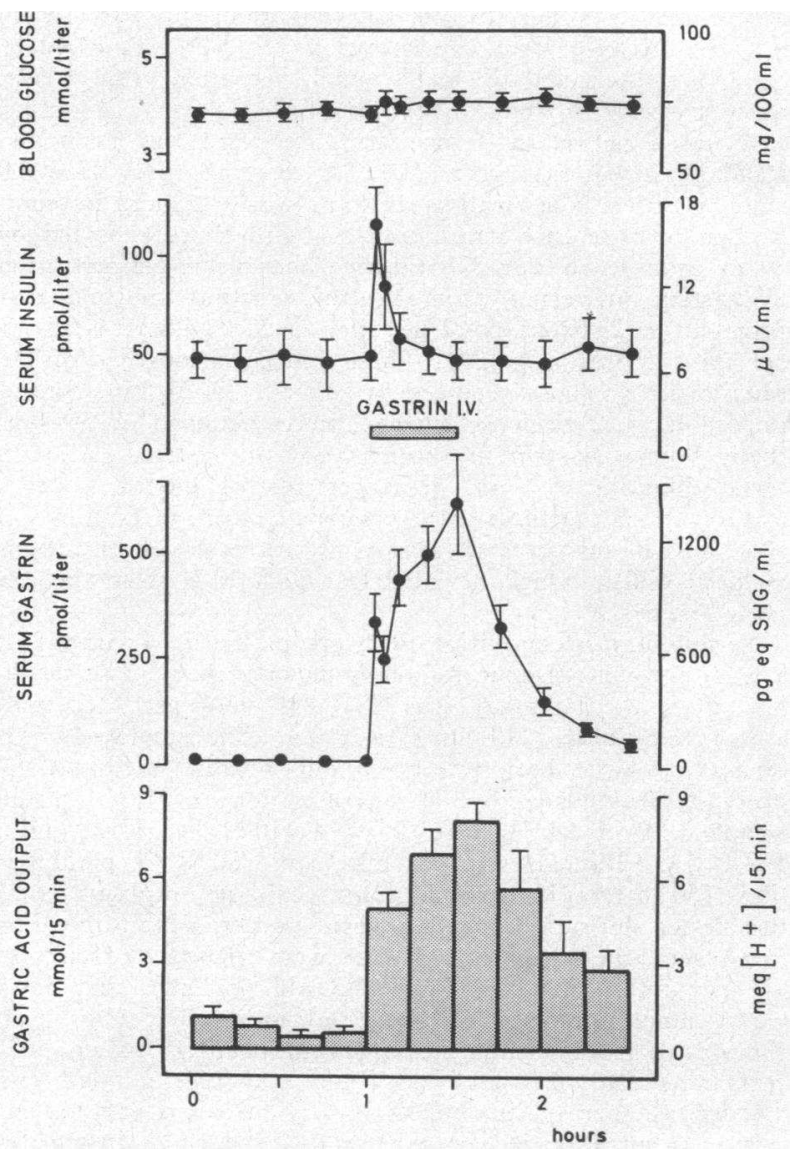

Figure 4 Blood glucose, serum insulin, serum gastrin concentrations, and gastric acid output during i.v. infusion of $12.5 \mathrm{ng} \mathrm{SHG} / \mathrm{kg}$ per min. The infusion was started with a single injection of $62.5 \mathrm{ng}$ gastrin $/ \mathrm{kg}$. The concentrations and gastric acid response are indicated as mean \pm SEM $(n=5)$. 


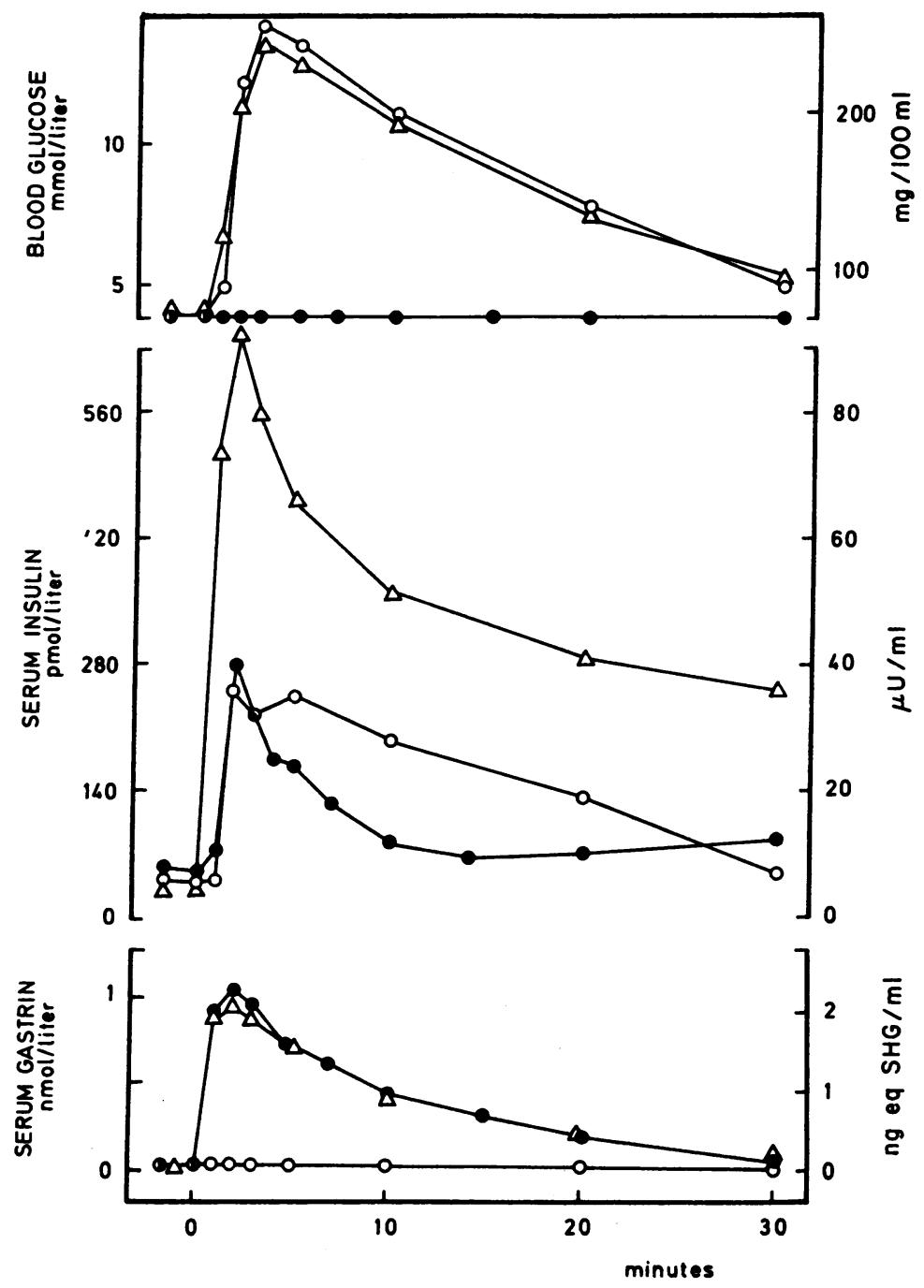

FIGURe 5 Blood glucose, serum insulin, and serum gastrin concentrations in one normal subject after i.v. injection of synthetic human gastrin I, $250 \mathrm{ng} / \mathrm{kg}$ body wt (๑), after i.v. injection of $25 \mathrm{~g}$ glucose (O), and after a synchronous i.v. injection of both $250 \mathrm{ng} / \mathrm{kg} \mathrm{SHG}$ and $25 \mathrm{~g}$ glucose $(\Delta)$.

Response to intravenous gastrin injections (Fig. 5 and Table I). The blood glucose concentration was elevated after gastrin injections. The rapid injection of gastrin caused an immediate insulin release with maximum concentration in peripheral venous serum after $2 \mathrm{~min}$. Insulin concentrations returned to basal levels within 10 min at a time, when the concentration of gastrin was still about 20 times above fasting levels. After $20 \mathrm{~min}$ a slight increase in insulin concentrations was found. The immediate insulin response to gastrin lasted less than $20 \mathrm{~min}$ for all doses of gastrin (Table I).

The insulin response to glucose was as rapid as the one to gastrin, and in one subject it reached similar levels. The glucose-induced response was, however, considerably more sustained (Fig. 5).

The dose-response interrelationship (Fig. 6, Tables I and II). There was no detectable insulin response to the smallest gastrin dose, $15.6 \mathrm{ng}$ SHG per $\mathrm{kg}$. Gastrin doses of $31.25 \mathrm{ng}$ per $\mathrm{kg}$ or more produced significant responses from the beta cells. $500 \mathrm{ng}$ per $\mathrm{kg}$ was the gastrin dose with greatest effect on insulin release. 1,000 ng gastrin per $\mathrm{kg}$ produced a smaller response than 500 ng per kg. The smallest gastrin dose caused a significant rise in serum gastrin concentrations. The maximum concentration was $110.9 \pm 14.1$ pmol per liter (244 $\pm 31.0 \mathrm{pg}$ eq SHG per $\mathrm{ml}$ ), which is of the same order as the 
TABLE I

Effect of Intravenous Injection of Increasing Doses of Synthetic Human Gastrin I on

\begin{tabular}{|c|c|c|c|c|c|c|c|}
\hline \multirow{2}{*}{$\begin{array}{l}\text { Dose of } \\
\text { gastrin }\end{array}$} & & & Time in \\
\hline & & -10 & -5 & 0 & 1 & 2 & 3 \\
\hline \multicolumn{8}{|l|}{$n g / k g$} \\
\hline \multirow[t]{3}{*}{15.625} & BG & $64.8 \pm 2.6$ & $64.0 \pm 2.5$ & $64.5 \pm 2.8$ & $64.8 \pm 2.6$ & $65.5 \pm 2.5$ & $65.5 \pm 2.5$ \\
\hline & SI & $5.0 \pm 0.7$ & $5.7 \pm 0.5$ & $6.0 \pm 1.4$ & $5.3 \pm 1.3$ & $4.3 \pm 0.9$ & $5.0 \pm 1.2$ \\
\hline & SG & $50.3 \pm 2.7$ & $50.8 \pm 2.6$ & $52.0 \pm 5.0$ & $245.8 \pm 44.8$ & $215.0 \pm 29.0$ & $170.3 \pm 20.4$ \\
\hline \multirow[t]{3}{*}{31.25} & $\mathrm{BG}$ & $63.8 \pm 1.9$ & $64.1 \pm 1.8$ & $65.0 \pm 1.7$ & $64.2 \pm 1.3$ & $64.3 \pm 2.1$ & $66.2 \pm 2.0$ \\
\hline & SI & $5.7 \pm 1.0$ & $5.8 \pm 0.9$ & $5.8 \pm 1.2$ & $6.5 \pm 1.1$ & $9.7 \pm 2.0$ & $9.8 \pm 2.1$ \\
\hline & SG & $50.3 \pm 6.1$ & $52.2 \pm 9.5$ & $53.7 \pm 8.0$ & $524.2 \pm 27.7$ & $478.3 \pm 31.4$ & $460.0 \pm 14.7$ \\
\hline \multirow[t]{3}{*}{62.50} & $\mathrm{BG}$ & $66.0 \pm 2.4$ & $66.0 \pm 2.2$ & $67.0 \pm 2.5$ & $66.3 \pm 2.4$ & $67.0 \pm 2.7$ & $66.3 \pm 2.9$ \\
\hline & SI & $5.8 \pm 1.6$ & $5.0 \pm 1.2$ & $5.8 \pm 1.4$ & $7.3 \pm 2.5$ & $10.8 \pm 2.7$ & $10.3 \pm 2.6$ \\
\hline & SG & $52.5 \pm 3.8$ & $53.3 \pm 3.6$ & $53.8 \pm 3.2$ & $931.7 \pm 40.2$ & $765.0 \pm 64.2$ & $613.3 \pm 33.7$ \\
\hline \multirow[t]{3}{*}{125.0} & BG & $68.0 \pm 2.6$ & $67.5 \pm 3.5$ & $67.0 \pm 2.3$ & $66.0 \pm 2.3$ & $67.8 \pm 3.2$ & $69.2 \pm 4.1$ \\
\hline & SI & $5.2 \pm 0.9$ & $6.0 \pm 0.7$ & $6.0 \pm 0.4$ & $7.8 \pm 0.4$ & $14.2 \pm 2.5$ & $13.3 \pm 1.6$ \\
\hline & SG & $43.0 \pm 4.8$ & $43.2 \pm 4.5$ & $43.3 \pm 5.6$ & $1550.0 \pm 241.0$ & $1308.0 \pm 133.0$ & $1161.0 \pm 119.0$ \\
\hline \multirow[t]{3}{*}{250.0} & BG & $69.0 \pm 3.3$ & $69.0 \pm 2.8$ & $69.7 \pm 3.0$ & $69.7 \pm 3.6$ & $72.3 \pm 4.3$ & $74.7 \pm 4.2$ \\
\hline & SI & $5.7 \pm 1.8$ & $5.3 \pm 2.1$ & $5.2 \pm 1.8$ & $7.8 \pm 2.6$ & $19.7 \pm 5.1$ & $16.5 \pm 5.1$ \\
\hline & SG & $35.8 \pm 5.8$ & $29.2 \pm 4.0$ & $27.0 \pm 3.5$ & $2466.7 \pm 386.8$ & $2816.7 \pm 170.8$ & $2533.3 \pm 138.8$ \\
\hline \multirow[t]{3}{*}{500.0} & $\mathrm{BG}$ & $64.0 \pm 3.4$ & $61.7 \pm 2.3$ & $63.3 \pm 2.4$ & $62.3 \pm 2.2$ & $62.5 \pm 2.4$ & $64.3 \pm 2.1$ \\
\hline & SI & $4.3 \pm 0.8$ & $4.3 \pm 1.0$ & $4.3 \pm 1.2$ & $11.7 \pm 5.4$ & $21.5 \pm 4.1$ & $22.2 \pm 6.8$ \\
\hline & SG & $38.8 \pm 3.0$ & $34.0 \pm 3.9$ & $31.7 \pm 4.4$ & $5050.0 \pm 283.7$ & $5875.0 \pm 461.9$ & $5400.0 \pm 418.0$ \\
\hline \multirow[t]{3}{*}{1000} & BG & $68.2 \pm 3.3$ & $68.7 \pm 3.1$ & $69.3 \pm 3.9$ & $69.0 \pm 2.9$ & $71.0 \pm 2.3$ & $71.8 \pm 2.2$ \\
\hline & SI & $3.7 \pm 0.8$ & $3.8 \pm 0.6$ & $3.7 \pm 0.9$ & $6.3 \pm 1.4$ & $16.7 \pm 4.3$ & $14.0 \pm 2.9$ \\
\hline & SG & $28.7 \pm 5.1$ & $30.3 \pm 4.9$ & $24.8 \pm 4.8$ & $10383.3 \pm 1461.6$ & $9550.0 \pm 1330.0$ & $8100.0 \pm 703.4$ \\
\hline
\end{tabular}

The concentrations are indicated as $\pm \mathrm{SEM}, \mathrm{n}=6$.

BG, blood glucose $(\mathrm{mg} / 100 \mathrm{ml})$; SI, serum insulin (microunits per milliliter); and SG, serum gastrin (picograms per milliliter).

maximum concentration observed during a protein-rich meal (Fig. 2).

Response to simultaneous intravenous injection of gastrin and glucose (Fig. 7, Tables II and III). Addition of $15.6 \mathrm{ng}$ SMG per $\mathrm{kg}$ to $25 \mathrm{~g}$ glucose increased the glucose-induced insulin response $(P<0.05)$. All doses of gastrin added to glucose increased the insulin concentrations immediately to a maximum in the 2 nd or 3rd min. The potentiation was maintained throughout $1 \mathrm{~h}$. Doses from $62.5 \mathrm{ng}$ per $\mathrm{kg}$ produced, when added to glucose, an insulin response per hour of a size similar to that of a protein-rich meal (Fig. 7). The integrated insulin responses to increasing doses of gastrin with and without glucose are compared in Table II.

Effect of gastrin on glucose disappearance rate (Table IV). The glucose disappearance rate after i.v. glucose administration was not changed by the addition of increasing doses of gastrin.

Response to intravenous glucose after prior administration of gastrin (Fig. 8 and Table V). Administra- tion of $15.6 \mathrm{ng}$ SHG per $\mathrm{kg}$, half an hour before i.v. injection of $25 \mathrm{~g}$ glucose caused an insignificant increase in insulin concentrations after the glucose administration $(P>0.05)$. The glucose disappearance rate decreased, but not significantly, after prior administration of gastrin (Table V).

\section{DISCUSSION}

The main conclusions to be drawn from the results presented above are that gastrin can stimulate a rapid and short-lived release of insulin. When gastrin concentrations are maintained within physiologic limits, gastrin potentiates only the glucose-induced insulin secretion, and is without effect on the basal insulin secretion. During oral glucose ingestion gastrin probably contributes very little to the insulin release. Gastrin may, however, stimulate the insulin secretion significantly during protein-rich meals.

Endogenous gastrin was found to be released immediately during the stimulus of an ordinary meal. The rise 
the Concentrations of Blood Glucose, Serum Insulin, and Serum Gastrin

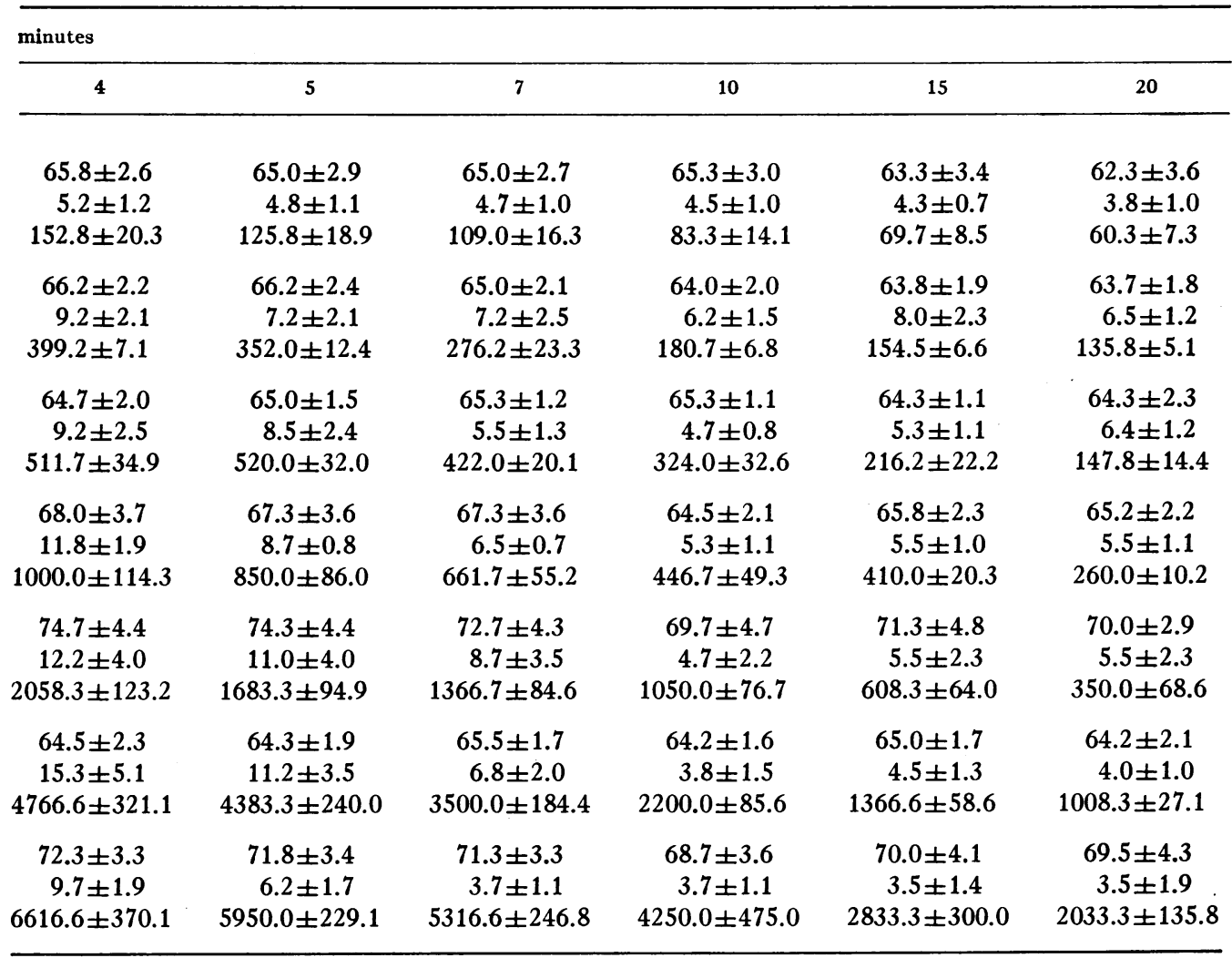

in serum gastrin was acute and preceded the increase in insulin concentrations. Hyperglycemia contributed little to the initial insulin response during the meal (Fig. 2 ). It hence appears that gastrin might be an insulin stimulator, probably in connection with other gut hormones and amino acids. A protein-rich meal is considered to be one of the strongest physiologic stimuli for gastrin secretion, and assessed from this stimulus the maximum physiologic gastrin concentrations in serum are in the order of 160 pmol per liter ( $350 \mathrm{pg}$ eq SHG per ml). That an insulinotropic action of gut hormones may exist was originally suggested by the difference in insulin response observed after oral and i.v. glucose administration (1-3). In the present investigation the glycemic stimulus was of the same magnitude whether glucose was administered parenterally or orally. Hence the apparent difference in insulin response may be taken as a measure cf the effect of the gut hormones. The size of the enteral hormonal stimulation was about two-thirds of the total insulin response to oral glucose, in accordance with the results of Perley and Kipnis (5). Since only moderate amounts of gastrin were released by ingestion of oral glucose, gastrin is probably not a major insulin secretagogue during an oral glucose loading.

The nature of the insulin response to exogenous gastrin was apparently independent of whether gastrin was administered as a rapid i.v. injection (Fig. 5) or as a 30 min infusion (Fig. 4). In both cases the beta cells responded with an immediate rise and a decline to basal levels within $10 \mathrm{~min}$. During the infusion gastric acid was aspirated continuously which makes it unlikely that secretin or cholecystokinin secretion was activated. When insulin responses were followed during a $30 \mathrm{~min}$ period after gastrin injection without gastric aspiration. a moderate late increase in insulin concentration was noted (Fig. 5). This could be due to other gut hormones being released by gastric acid secreted in response to gastrin, although studies on the effect of acid installation in duodenum on insulin release are controversial so far ( 7 , $14,27-31)$. The present experiments hence suggest that 
TABLE II

Integrated Insulin Response $(\mu \mathrm{U} / \mathrm{ml} \text { per } 20 \mathrm{~min})^{*}$ in Six Normal Subjects after Intravenous Injection of Synthetic Human Gastrin $I(A)$ and Synchronously with $25 \mathrm{~g}$ Glucose (B).

\begin{tabular}{|c|c|c|c|c|c|c|c|c|c|}
\hline & & \multicolumn{8}{|c|}{ Dose of gastrin } \\
\hline & & 0 & 15.625 & 31.25 & 62.50 & 125.0 & 250.0 & 500.0 & 1000 \\
\hline & & \multicolumn{8}{|c|}{$n g / k g$} \\
\hline \multirow[t]{2}{*}{ A } & Mean & - & 0 & $\begin{array}{c}5.3 \\
(37.0)\end{array}$ & $\begin{array}{c}17.3 \\
(121.1)\end{array}$ & $\begin{array}{c}28.6 \\
(199.9)\end{array}$ & $\begin{array}{c}50.3 \\
(352.0)\end{array}$ & $\begin{array}{c}79.8 \\
(558.8)\end{array}$ & $\begin{array}{c}37.7 \\
(263.6)\end{array}$ \\
\hline & SEM & - & - & $\begin{array}{c}2.9 \\
(20.6)\end{array}$ & $\begin{array}{c}5.1 \\
(35.9)\end{array}$ & $\begin{array}{c}4.4 \\
(31.0)\end{array}$ & $\begin{array}{r}11.8 \\
(82.4)\end{array}$ & $\begin{array}{c}24.2 \\
(169.5)\end{array}$ & $\begin{array}{c}10.5 \\
(73.8)\end{array}$ \\
\hline \multirow[t]{2}{*}{ B } & Mean & $\begin{array}{c}331.0 \\
(2317.0)\end{array}$ & $\begin{array}{c}619.2 \\
(4333.0)\end{array}$ & 一 & $\begin{array}{c}658.5 \\
(4609.5)\end{array}$ & 一 & $\begin{array}{c}713.8 \\
(4996.6)\end{array}$ & - & - \\
\hline & SEM & $\begin{array}{c}43.9 \\
(328.3)\end{array}$ & $\begin{array}{c}140.6 \\
(984.2)\end{array}$ & - & $\begin{array}{c}233.5 \\
(1681.0)\end{array}$ & - & $\begin{array}{c}113.2 \\
(791.4)\end{array}$ & - & - \\
\hline
\end{tabular}

* Insulin response in pmol/liter per 20 min indicated in the brackets.

gastrin may affect the beta cells in two ways: (a) by a direct effect on the acutely releasable pool of insulin in accordance with the conception of a two-pool system in man (32), and possibly (b) by an indirect effect mediated through activation of other gastrointestinal hormones released by acid in duodenum and jejunum. The magnitude and steepness in the increase of gastrin concentrations seem to govern the insulin response rather than the total integrated gastrin stimulus.

The dose-response studies of the effect on basal insulin secretion showed that the gastrin doses required for a significant insulin response resulted in unphysiologic concentrations of gastrin in serum. In contrast the glucose-stimulated insulin secretion was significantly potentiated by small doses of gastrin, resulting in serum gastrin levels within physiologic limits. The effect was not additive, but obviously potentiating and direct since the increase in the glucose-mediated insulin release was observed in the 1 st min (Fig. 5 and Table III). It is notable that the gastrin-potentiated insulin increase did not influence the glucose disappearance rate (Table IV). This observation supports the findings of Chisholm, Young, and Lazarus (30) and Dupré, Curtis, Unger, Waddell, and Beck (7), who inferred that the effect of gut hormones on glucose disposal probably does not depend solely on stimulation of insulin secretion. A simi-

TABLE III Effect of Intravenous Injection of $25 \mathrm{~g}$ Glucose and Increasing Doses of Synthetic Human Gastrin I

\begin{tabular}{|c|c|c|c|c|c|c|}
\hline \multirow{2}{*}{$\begin{array}{l}\text { Dose of } \\
\text { gastrin }\end{array}$} & & \multicolumn{5}{|r|}{ Time in } \\
\hline & & -5 & 0 & 1 & 2 & 3 \\
\hline \multicolumn{7}{|l|}{$n g / k g$} \\
\hline 0.0 & $\begin{array}{l}\text { BG } \\
\text { SI } \\
\text { SG }\end{array}$ & $\begin{array}{r}63.0 \pm 4.0 \\
3.3 \pm 0.9 \\
44.5 \pm 4.1\end{array}$ & $\begin{array}{r}64.3 \pm 4.3 \\
3.0 \pm 1.0 \\
38.7 \pm 4.4\end{array}$ & $\begin{array}{c}141.3 \pm 23.3 \\
9.0 \pm 4.1 \\
43.0 \pm 5.5\end{array}$ & $\begin{array}{c}240.8 \pm 15.0 \\
26.2 \pm 4.3 \\
34.8 \pm 5.2\end{array}$ & $\begin{array}{c}230.8 \pm 15.9 \\
29.3 \pm 4.3 \\
35.3 \pm 5.3\end{array}$ \\
\hline 15.625 & $\begin{array}{l}\text { BG } \\
\text { SI } \\
\text { SG }\end{array}$ & $\begin{array}{r}58.7 \pm 2.8 \\
3.7 \pm 0.9 \\
31.5 \pm 9.6\end{array}$ & $\begin{array}{r}60.3 \pm 2.2 \\
3.5 \pm 1.1 \\
32.8 \pm 9.9\end{array}$ & $\begin{array}{r}166.7 \pm 26.7 \\
41.5 \pm 11.6 \\
131.7 \pm 32.9\end{array}$ & $\begin{array}{c}217.7 \pm 22.5 \\
48.0 \pm 7.6 \\
156.7 \pm 14.5\end{array}$ & $\begin{array}{r}217.7 \pm 22.6 \\
52.8 \pm 12.5 \\
144.4 \pm 12.0\end{array}$ \\
\hline 62.50 & $\begin{array}{l}\text { BG } \\
\text { SI } \\
\text { SG }\end{array}$ & $\begin{array}{r}60.3 \pm 3.8 \\
3.2 \pm 1.0 \\
35.0 \pm 8.8\end{array}$ & $\begin{array}{r}60.0 \pm 3.9 \\
2.7 \pm 0.2 \\
31.7 \pm 9.8\end{array}$ & $\begin{array}{c}209.5 \pm 38.1 \\
55.7 \pm 9.8 \\
685.0 \pm 85.9\end{array}$ & $\begin{array}{r}263.0 \pm 24.9 \\
66.6 \pm 22.3 \\
593.3 \pm 20.5\end{array}$ & $\begin{aligned} 235.3 & \pm 16.1 \\
68.5 & \pm 33.8 \\
608.0 & \pm 118.6\end{aligned}$ \\
\hline 250.0 & $\begin{array}{l}\text { BG } \\
\text { SI } \\
\text { SG }\end{array}$ & $\begin{array}{r}60.0 \pm 2.7 \\
4.5 \pm 0.7 \\
31.3 \pm 6.3\end{array}$ & $\begin{array}{r}58.7 \pm 2.8 \\
4.8 \pm 0.9 \\
29.8 \pm 4.7\end{array}$ & $\begin{array}{c}143.0 \pm 22.2 \\
34.3 \pm 10.4 \\
2270.0 \pm 338.0\end{array}$ & $\begin{aligned} 204.3 & \pm 22.2 \\
58.3 & \pm 14.2 \\
2353 & \pm 245.9\end{aligned}$ & $\begin{array}{c}210.8 \pm 12.8 \\
55.3 \pm 8.8 \\
2190.0 \pm 182.8\end{array}$ \\
\hline
\end{tabular}

The concentrations are indicated as mean \pm SEM, $n=6$. 

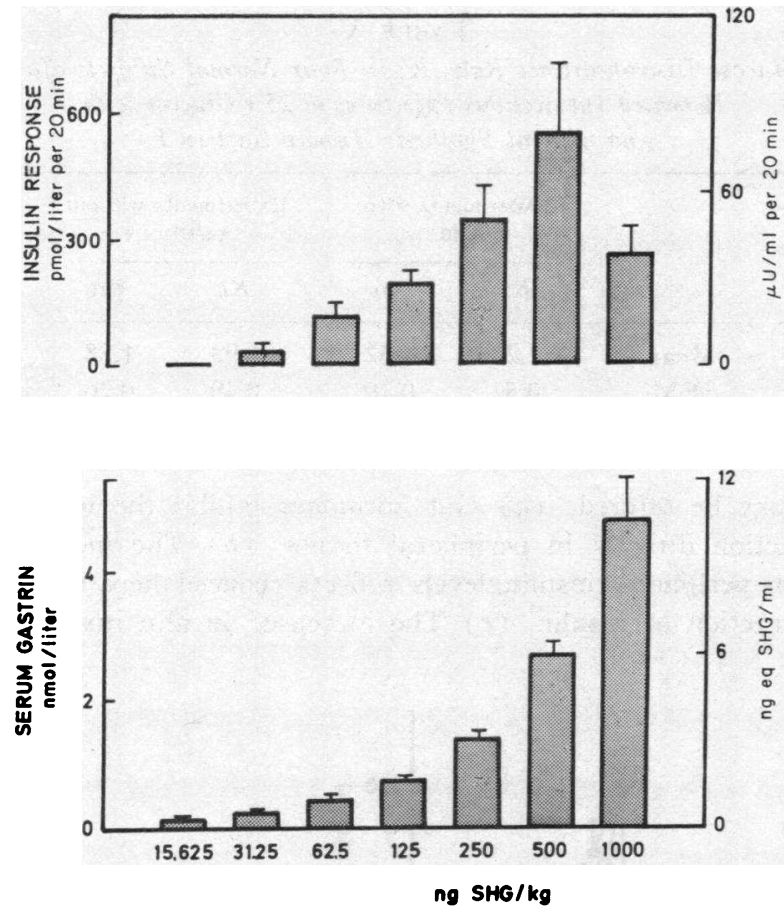

FiguRe 6 Integrated insulin response and maximal serum gastrin concentrations after i.v. injection of increasing doses of SHG. The responses and concentrations are indicated as mean $\pm \operatorname{SEM}(n=6)$.

lar result was obtained by Meade, Kneubuhler, Barboriak, and Schulte (33) as to the effect of cholecystokinin in dogs. In view of the C-terminal structural identity of gastrin and cholecystokinin, it is possible that
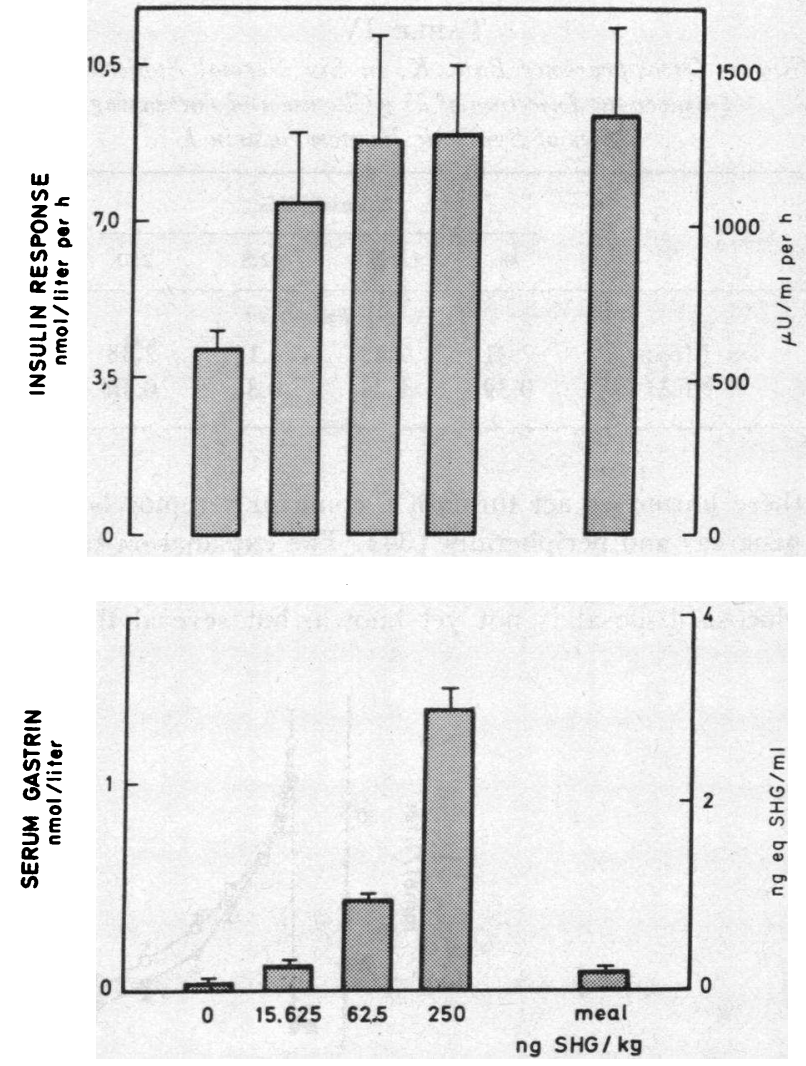

FIGURE 7 Integrated insulin response and maximal serum gastrin concentrations after i.v. injection of $25 \mathrm{~g}$ glucose and increasing doses of synthetic human gastrin. As reference the insulin response and gastrin concentration during a protein-rich meal are shown. The results are indicated as mean $\pm \operatorname{SEM}(n=6$, for the meal $n=8)$.

on the Concentrations of Blood Glucose, Serum Insulin, and Serum Gastrin

\begin{tabular}{ccccccc}
\hline minutes & \multicolumn{7}{c}{ 30 } & 40 & 50 & 60 \\
\hline 5 & 10 & 20 & & & & \\
& & & & & & \\
$213.3 \pm 12.1$ & $180.0 \pm 13.0$ & $136.7 \pm 9.4$ & $109.7 \pm 11.0$ & $91.2 \pm 12.0$ & $75.3 \pm 9.2$ & $68.4 \pm 8.4$ \\
$24.7 \pm 3.4$ & $17.2 \pm 2.9$ & $14.8 \pm 1.7$ & $11.2 \pm 1.9$ & $9.8 \pm 2.0$ & $8.0 \pm 2.3$ & $4.8 \pm 2.0$ \\
$38.0 \pm 4.4$ & $35.5 \pm 4.2$ & $36.1 \pm 4.0$ & $35.5 \pm 5.0$ & $37.2 \pm 4.3$ & $35.5 \pm 4.9$ & $36.8 \pm 4.6$ \\
$213.7 \pm 23.4$ & $178.0 \pm 4.6$ & $145.3 \pm 8.9$ & $109.3 \pm 7.0$ & $87.0 \pm 10.5$ & $71.0 \pm 9.2$ & $59.7 \pm 7.7$ \\
$45.3 \pm 11.7$ & $32.8 \pm 8.9$ & $21.7 \pm 5.5$ & $19.2 \pm 4.2$ & $12.7 \pm 3.2$ & $10.8 \pm 2.9$ & $10.7 \pm 2.9$ \\
$121.3 \pm 12.5$ & $80.8 \pm 17.0$ & $57.5 \pm 19.3$ & $47.7 \pm 13.2$ & $42.5 \pm 11.9$ & $37.5 \pm 11.1$ & $34.2 \pm 9.1$ \\
$220.8 \pm 16.7$ & $183.0 \pm 10.4$ & $141.0 \pm 7.1$ & $119.5 \pm 10.1$ & $94.7 \pm 9.5$ & $76.7 \pm 7.6$ & $66.3 \pm 4.7$ \\
$47.8 \pm 21.9$ & $28.5 \pm 7.0$ & $22.5 \pm 5.1$ & $22.0 \pm 4.2$ & $19.0 \pm 3.2$ & $15.7 \pm 2.8$ & $11.3 \pm 2.1$ \\
$502.0 \pm 106.2$ & $276.4 \pm 69.0$ & $145.4 \pm 32.9$ & $80.2 \pm 10.3$ & $54.8 \pm 15.0$ & $48.2 \pm 13.8$ & $44.8 \pm 14.5$ \\
$203.2 \pm 6.5$ & $170.7 \pm 3.5$ & $130.0 \pm 5.7$ & $105.3 \pm 8.0$ & $82.3 \pm 10.5$ & $73.3 \pm 9.0$ & $66.0 \pm 6.8$ \\
$48.8 \pm 7.5$ & $39.0 \pm 6.1$ & $31.7 \pm 5.5$ & $22.7 \pm 4.8$ & $17.5 \pm 3.6$ & $11.0 \pm 2.7$ & $9.5 \pm 3.7$ \\
$1665.0 \pm 129.6$ & $983.3 \pm 76.2$ & $280.0 \pm 33.1$ & $144.2 \pm 11.1$ & $90.3 \pm 6.5$ & $71.0 \pm 3.1$ & $61.8 \pm 3.6$
\end{tabular}


TABLE IV

Glucose Disappearance Rate, $K$, in Six Normal Subjects after Intravenous Injection of $25 \mathrm{~g}$ Glucose and Increasing Doses of Synthetic Human Gastrin I

\begin{tabular}{ccccc}
\hline & \multicolumn{4}{c}{ Dose of SHG } \\
\cline { 2 - 5 } & 0 & 15.625 & 62.5 & 250 \\
\hline \multirow{4}{*}{ Mean $k$ kg body $w t$} \\
SEM & 2.31 & 2.49 & 2.11 & 2.38 \\
& 0.39 & 0.31 & 0.33 & 0.46 \\
\hline
\end{tabular}

these hormones act through a common receptor both in pancreas and peripherally (34). The explanation for the apparent lack of influence of immunoreactive insulin on glucose disposal is not yet known, but several theories
TABLE V

Glucose Disappearance Rate, $K$, in Four Normal Subjects after Repeated Intravenous Injections of $25 \mathrm{~g}$ Glucose with and without Synthetic Human Gastrin I

\begin{tabular}{ccccccc}
\hline & \multicolumn{2}{c}{$\begin{array}{c}\text { Experiments with } \\
\text { gastrin i.v. }\end{array}$} & & \multicolumn{2}{c}{$\begin{array}{c}\text { Experiments without } \\
\text { gastrin i.v. }\end{array}$} \\
\cline { 2 - 3 } \cline { 5 - 6 } & $K_{\mathrm{I}}$ & $K_{\mathrm{II}}$ & & $K_{\mathrm{I}}$ & $K_{\mathrm{II}}$ \\
\hline Mean & 2.27 & 1.52 & & 1.93 & 1.88 \\
SEM & 0.54 & 0.40 & & 0.49 & 0.26 \\
\hline
\end{tabular}

may be offered: (a) Gut hormones inhibit the insulin action directly in peripheral tissues. (b) The increase in peripheral insulin levels reflects reduced hepatic extraction of insulin. (c) The increased insulin immuno-
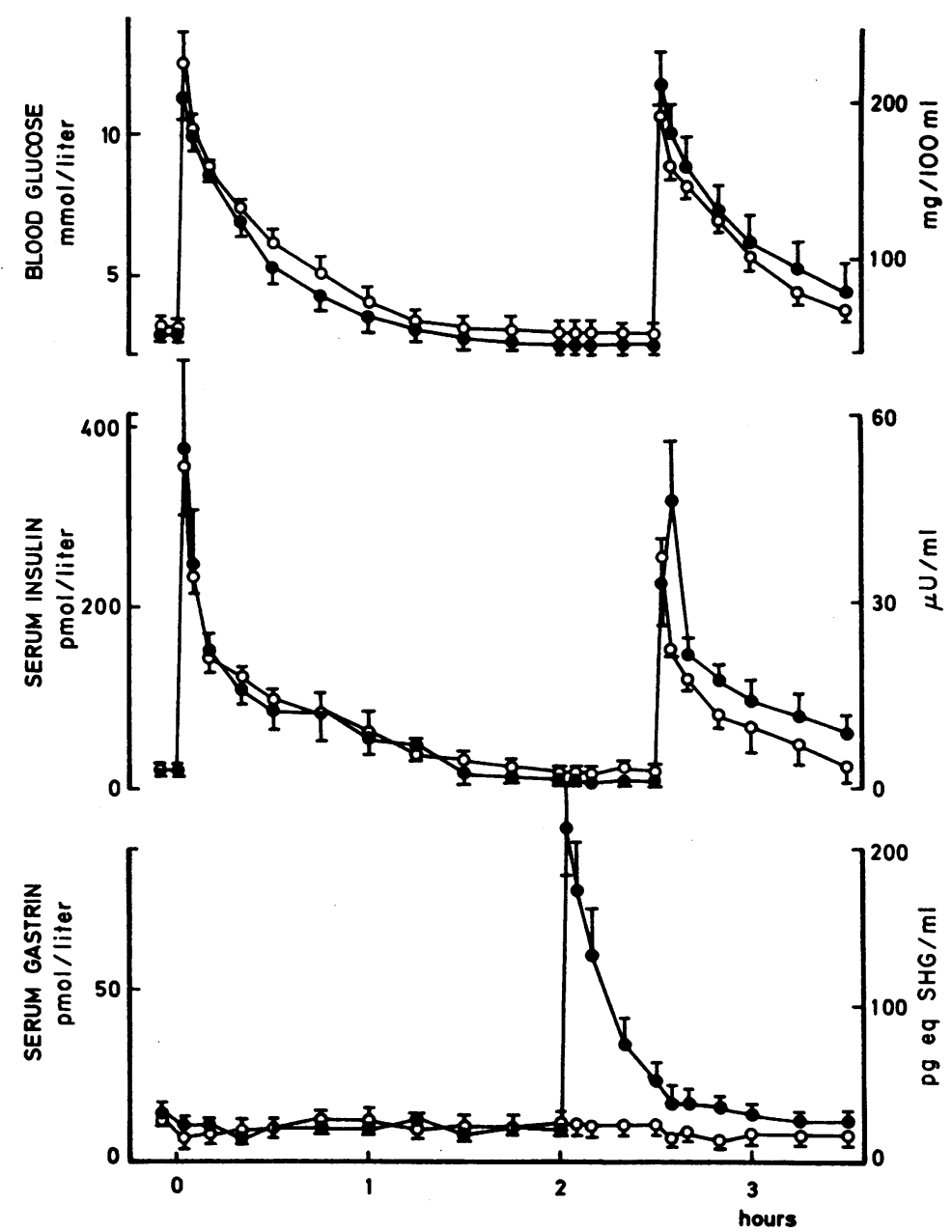

FIGURE 8 Blood glucose, serum insulin, and serum gastrin concentrations during repeated i.v. injection of $25 \mathrm{~g}$ glucose $(O)$. The experiment was repeated in the same subjects with i.v. injection of $15.625 \mathrm{ng} \mathrm{SHG} / \mathrm{kg} 30 \mathrm{~min}$ before the second glucose load $(\bullet)$. 
reactivity represents a less active moiety of insulin, for instance proinsulin. (d) The glucose disappearance curve employed in the present study reflects glucose distribution unrelated to insulin action. (e) Gastrin stimulates glucagon secretion with ensuing glycogenolysis and gluconeogenesis.

It has been reported (35) that secretin potentiated the glucose-induced insulin secretion by a dual action. Using a similar experimental design, we could not demonstrate a dual effect of gastrin on insulin release or glucose disposal. The conclusions from the present study are drawn with two reservations. Firstly, the role of a possible local secretion of gastrin from the D-cells in the islets is still undetermined. Secondly, the different endogenous gastrin components $(36,37)$ may show different biological properties.

\section{ACKNOWLEDGMENTS}

The skillful technical assistance of Ninna Haack and Ulla Soegaard is gratefully acknowledged.

The study was supported by grants from Statens Lægevidenskabelige Forskningsråd, j.nr. 512-1048 and 512-1323, Forskningsfondet for Stork $\varnothing$ benhavn, Fær $\varnothing e r n e$ og Gr $\varnothing$ nland, and Chr. X's Fond.

\section{REFERENCES}

1. McIntyre, N., C. D. Holdsworth, and D. S. Turner. 1964. New interpretation of oral glucose tolerance. Lancet. $2: 20$.

2. McIntyre, N., C. D. Holdsworth, and D. S. Turner. 1965. Intestinal factors in the control of insulin secretion. J. Clin. Endocrinol. Metab. 25: 1317.

3. Elrick, H., L. Stimmler, C. J. Hlad, Jr., and Y. Arai. 1964. Plasma insulin response to oral and intravenous glucose administration. J. Clin. Endocrinol. Metab. 24: 1076.

4. Unger, R. H., and A. M. Eisentraut. 1969. Enteroinsular axis. Arch. Intern. Med. 123: 261.

5. Perley, M. J., and D. M. Kipnis. 1967. Plasma insulin responses to oral and intravenous glucose: studies in normal and diabetic subjects. J. Clin. Invest. 46: 1954.

6. Unger, R. H., H. Ketterer, J. Dupré, and A. M. Eisentraut. 1967. The effects of secretin, pancreozymin, and gastrin on insulin and glucagon secretion in anesthetized dogs. J. Clin. Invest. 46: 630.

7. Dupré, J., J. D. Curtis, R. H. Unger, R. W. Waddell, and J. Beck. 1969. Effects of secretin, pancreozymin, or gastrin on the response of the endocrine pancreas to administration of glucose or arginine in man. J. Clin. Invest. $48: 745$.

8. Kaneto, A., Y. Tasaka, K. Kosaka, and K. Nakao. 1969. Stimulation of insulin secretion by the C-terminal tetrapeptide amide of gastrin. Endocrinology. 84: 1098.

9. Ohgawara, H., Y. Mizuno, Y. Tasaka, and K. Kosaka. 1969. Effect of the C-terminal tetrapeptide amide of gastrin on insulin secretion in man. J. Clin. Endocrinol. Metab. 29: 1261 .

10. Kikuchi, M., T. Kuzuya, and T. Ide. 1971. Plasma insulin response to intravenous administration of tetragastrin in man. Metab. (Clin. Exp.). 20: 433.
11. Iversen, J. 1971. Secretion of glucagon from the isolated, perfused canine pancrease. J. Clin. Invest. 50: 2123.

12. Jarett, R. J., and N. M. Cohen. 1967. Intestinal hormones and plasma insulin: some observations on glucagon, secretin, and gastrin. Lancet. 2: 861 .

13. Lazarus, N. R., N. R. Voyles, S. Devrim, T. Tanese, and L. Recant. 1968. Extra-gastrointestinal effects of secretin, gastrin, and pancreozymin. Lancet. 2 : 248.

14. Kaess, H., and G. Schlierf. 1968. Untersuchungen über die exokrine und endokrine Pankreasfunktion nach exogener und endogener Stimulation mit Secretin sowie Pentagastrin. Verh. Dtsch. Ges. Inn. Med. 74: 225.

15. Buchanan, K. D., J. E. Vance, and R. H. Williams. 1969. Insulin and glucagon release from isolated islets of Langerhans. Effect of enteric factors. Diabetes. 18: 381.

16. Rehfeld, J. F. 1971. Effect of gastrin and its C-terminal tetrapeptide on insulin secretion in man. Acta Endocrinol. (Copenhagen). $66: 169$.

17. Lernmark, A., B. Hellman, and H. G. Coore. 1969. Effect of gastrin on the release of insulin in vitro. $J$. Endocrinol. 43: 371.

18. Hansky, J., and M. D. Cain. 1969. Radioimmunoassay of gastrin in human serum. Lancet. 2: 1388.

19. Yalow, R. S., and S. A. Berson. 1970. Radioimmunoassay of gastrin. Gastroenterology. 58: 1 .

20. McGuigan, J. E., and W. L. Trudeau. 1970. Studies with antibodies to gastrin: radioimmunoassay in human serum and physiological studies. Gastroenterology. 58: 139.

21. Stadil, F., and J. F. Rehfeld. 1971. Radioimmunoassay of gastrin in human serum. Scand. J. Gastroenterol. 6(Suppl.) : 61 .

22. Rune, S. J. 1966. Comparison of the rates of gastric acid secretion in man after ingestion of food and after maximal stimulation with histamine. Gut. 7: 344 .

23. Stadil, F., and J. F. Rehfeld. 1972. Preparation of ${ }^{125} \mathrm{I}-$ synthetic human gastrin for the radioimmunoassay of gastrin. Scand. J. Clin. Lab. Invest. 30: 361 .

24. Rehfeld, J. F., F. Stadil, and B. Rubin. 1972. Production and evaluation of antibodies for the radioimmunoassay of gastrin. Scand. J. Clin. Lab. Invest. 30: 221.

25. Ganguli, P. C., and W. M. Hunter. 1972 Radioimmunoassay of gastrin in human plasma. J. Physiol. (Lond.). 220: 499.

26. Oerskov, H. 1967. Wick-chromatography for the immunoassay of insulin. Scand. J. Clin. Lab. Invest. 20: 297.

27. Boyns, D. R., R. J. Jarrett, and H. Keen. 1967. Intestinal hormones and plasma insulin: an insulinotropic action of secretin. Br. Med.J. $2: 676$.

28. Mahler, R. J., and H. Weisberg. 1968. Failure of endogenous stimulation of secretin and pancreozymin release to influence serum-insulin. Lancet. 1 : 488.

29. Kaess, H., and G. Schlierf. 1969. Veränderungen des Blutzuckers und der Plasmainsulinkonzentration nach Stimulierung der endogenen Sekretionfreisetzung. Diabetologia. 5 : 228.

30. Chisholm, D. J., J. D. Young, and L. Lazarus. 1969. The gastrointestinal stimulus to insulin release. I. Secretin. J. Clin. Invest. $48: 1453$.

31. Kaess, H., G. Schlierf, and J. G. von Mikulicz-Radecki. 1970. Effect of intraduodenal installation of hydrochloric 
acid on plasma insulin levels of patients with portocaval shunts. Metab. (Clin. Exp.). 19: 214.

32. Porte, D. J., Jr., and A. A. Pupo. 1969. Insulin responses to glucose: evidence for a two pool system in man. J. Clin. Invest. 48: 2309.

33. Meade, R. C., H. A. Kneubuhler, J. J. Barboriak, and W. J. Schulte. 1969. Absence of glucose response to physiologic levels of serum insulin. Diabetes. 18: 397.

34. Grossman, M. I. 1970. Hypothesis. Gastrin, cholecystokinin and secretin act on one receptor. Lancet. 1: 1088.
35. Kraegen, E. W., D. J. Chisholm, J. D. Young, and L. Lazarus. 1970. The gastrointestinal stimulus to insulin release. II. A dual action of secretion. J. Clin. Invest. $49: 524$.

36. Yalow, R. S., and S. A. Berson. 1971. Further studies on the nature of immunoreactive gastrin in human plasma. Gastroenterology. 60: 203.

37. Rehfeld, J. F. 1972. Three components of gastrin in human serum. Gel filtration studies on the molecular size of immunoreactive gastrin in serum. Biochim. Biophys. Acta. 285: 364 . 